\title{
CHARACTERISTICS OF THE TOWNHOUSE IN SEMARANG KARAKTERISTIK TOWNHOUSE DI SEMARANG
}

\author{
Syarif Hidayatullah $^{1)}$, Carina Sarasati' ${ }^{2}$, Adi Sasmito ${ }^{3)}$ \\ Prodi Arsitektur, Fakultas Teknik, Universitas Pandanaran Semarang \\ syarifhidayatullah1994@gmail.com ${ }^{1)}$ \\ carinasarasati@gmail.com ${ }^{2}$ \\ sasmitoadi308@gmail.com ${ }^{3)}$
}

\begin{abstract}
Abstrak
Kota Semarang adalah ibukota provinsi jawa tengah sekaligus menjadi salah satu kota yang paling berkembang dijawa tengah, pertumbuhan ekonomi dan juga bisnis yang diimbangi pula dengan tingkat pertumbuhan penduduk yang tinggi, menurut data BPS di kota semarang dengan kenaikan 1,31\% dari tahun 2018-2020, pertumbuhan penduduk menyebabkan semakin meningkatnya kebutuhan hunian/rumah di semarang,hunian di pusat kota saat ini lebih didominasi oleh model hunian seperti apartemen dan kondominium, hal ini seiring dengan menyempitnya lahan kosong ditengah kota, tetepai Sebagian besar masyarakat masih lebih cenderung menyukai model hunian yang langsung berhubungan dengan tanah atau dikenal dengan (landed house), saat ini di semarang banyak pengembang yang mengusung perumahan model townhouse dan cluster, namun prakteknya dilapangan masih belum sesuai dengan karakteristik perumahan tersebut, hal ini dapat menjadi salah persepsi dimasyarakat terhadap perumahan townhouse dan perumahan cluster tersebut.

Kajian diawali dengan mempelajari pengertian dan karakteristik townhouse juga karakteristik cluster, dengan studi kasus di beberapa perumahan townhouse yang ada di semarang, dengan melakukan observasi dan penelusuran data base online yang dilakukan ternyata perumahan cluster yang ada disemarang menerapkan karakteristik perumahan townhouse.
\end{abstract}

Kata kunci: Townhouse, Karakteristik,Kota Semarang.

\section{Abstract}

The city of Semarang is the capital of the province of Central Java as well as being one of the most developed cities in Central Java, economic and business growth is also offset by a high population growth rate, according to BPS data in the city of Semarang with an increase of 1.31\% from 2018-2020, population growth causes the increasing need for housing/houses in Semarang, housing in the city center is currently more dominated by residential models such as apartments and condominiums, this is in line with the narrowing of vacant land in the middle of the city, but most people still prefer to like residential models that are directly related to land or known as (landed house), currently in Semarang there are many developers who carry townhouse and cluster housing models, but the practice in the field is still not in accordance with the characteristics of these housings, this can be a misperception in the community towards townhouse housing and cluster housing. it ut.

The study begins by studying the definition and characteristics of townhouses as well as cluster characteristics, with case studies in several townhouse housings in Semarang, by observing and searching online data bases, it turns out that cluster housing in Semarang applies townhouse characteristics.

Keywords: Townhouse, Characteristics, Semarang City. 


\section{PENDAhULUAN}

Kota Semarang adalah ibukota provinsi jawa tengah sekaligus menjadi salah satu kota yang paling berkembang dijawa tengah, pertumbuhan ekonomi dan juga bisnis yang diimbangi pula dengan tingkat pertumbuhan penduduk yang tinggi, menurut data BPS di kota semarang dengan kenaikan 1,31\% dari tahun 2018-2020, pertumbuhan penduduk menyebabkan semakin meningkatnya kebutuhan hunian/rumah di semarang,hunian di pusat kota saat ini lebih didominasi oleh model hunian seperti apartemen dan kondominium, hal ini seiring dengan menyempitnya lahan kosong ditengah kota, tetepai Sebagian besar masyarakat masih lebih cenderung menyukai model hunian yang langsung berhubungan dengan tanah atau dikenal dengan (landed house).

Townhouse adalah istilah yang digunakan untuk sebuah perumahan berbentuk cluster namun dengan jumlah unit yang sedikit terletak di dekat kota. Sedangkan perumahan cluster pada dasarnya adalah sekumpulan rumah yang dibangun biasanya di satu wilayah pinggir kota yang pada umumnya memiliki jumlah rumah yang lebih banyak daripada Townhouse. Sekitar 100 sampai 300 unit rumah, disisi lain Townhouse memiliki sederet fasilitas umum seperti jogging track, kolam renang, ruang terbuka hijau, club house serta sistem keamanan yang cukup baik. Fasilitas yang lengkap, bangunan yang megah dan fasad yang elegan adalah daya tarik utama dari rumah Townhouse, maka dari itu bangunan rumah dengan model Townhouse menjangkau pasar di kalangan atas yang menginginkan alternatif hunian eksklusif dengan segala fasilitasnya demi menjaga privasi mereka, selain itu, tuntutan dekat dengan fasilitas public, seperti pusat belanja,Pendidikan, rumah sakit, dan pusat bisnis serta pemukiman sekitar menjadi pertimbangannya, saat ini di semarang banyak pengembang yang mengusung perumahan model townhouse dan cluster, namun prakteknya dilapangan masih belum sesuai dengan karakteristik perumahan tersebut, hal ini dapat menjadi salah persepsi dimasyarakat terhadap perumahan townhouse dan perumahan cluster tersebut.

Melihat fenomena dan permasalahan diatas, maka dibutuhkan penilitian terkait karakteristik perumahan townhouse dan juga karakteristik perumahan cluster.

\section{TINJAUAN TEORI}

Menurut Kamus Real Estate (2004) Perumahan Cluster adalah perumahan cluster merupakan unit hunian yang dikelompokkan secara bersama-sama dan tertutup dengan memberikan area terbuka sebagai area umum. Area terbuka pada umumnya dialokasikan ke pejalan kaki dan digunakan sebagai fasilitas rekreasi bersama, sehingga tercipta suatu lingkungan yang nyaman dan menarik.

Menurut Widodo (2012), perumahan cluster adalah perumahan yang berkonsep tertutup (cluster) yang menggunakan satu akses (gate) untuk keluar dan masuk, penerapan satu akses ini memungkinkan semua mobilitas yang terjadi didalam cluster tersebut dapat dipantau oleh petugas keamanan.

Pada awalnya istilah Townhouse berkembang dari kata Row House atau rumah Bandar yang didefinisikan sebagai "salah satu grup atau baris yang berkelanjutan rumah yang memiliki struktur dan tampilan seragam, sering kali disatukan dinding samping yang umum. " (Stein, 1968: 1150 dalam Akbar, 2009: 13).

Townhouse adalah rumah yang terkait dengan unit-unit rumah lainnya. Dalam komunitas Townhouse, penghuni difasilitasi dengan area-area komunal, seperti taman, kolam renang, fasilitas olahraga, dan lain-lain (De Chiara, 1995).

"Townhouse adalah rumah deret dengan layout ruang kompak dan fungsional, dan tidak memiliki halaman 
sendiri." (Yuwono dan Azhar, housing Estate n.d.)

Townhouse adalah sebuah komplek perumahan yang terletak di dalam kota dimana setiap unitnya seragam, saling berdempet, membentuk baris, dan dibatasi oleh dinding yang digunakan bersama. Pada umumnya, Townhouse merupakan tipe hunian low rise dengan sistem utilitas yang lengkap dalam tiap unitnya (Llyod, 1990).

Menurut Tjiptono dan Afandi, (2006) Townhouse biasanya dibangun di atas tanah dengan luas area kurang dari 5000 $\mathrm{m} 2$, dengan jumlah unit yang terbatas. Townhouse yang dibangun secara vertikal (2-3 lantai), saling berderetan, dengan lebar dan panjang, menghasilkan jumlah massa bangunan yang lebih banyak, Karakteristik fisik bangunan merupakan ciri/karakter bangunan yang dapat ditangkap secara visual dan terukur, seperti : luas dan ukuran bangunan, jumlah lantai, desain (gaya arsitektur) bangunan, material, luas dan tata letak ruang, konstruksi, ketersediaan garasi/carport, dan halaman.

\section{METODOLOGI PENELITIAN}

Penelitian ini menggunakan pendekatan kualitatif yaitu pendekatan yang dilakukan untuk menjelaskan suatu fenomena yang sesuai apa yang dikatakan oleh Bogdan dan Taylor (1975) dalam Moleong (2002: 3) yang menyatakan "metodologi kualitatif" sebagai prosedur penelitian yang menghasilkan data deskriptif berupa kata kata tertulis atau lisan dari orang-orang dan perilaku yang dapat diamati.Bagian ini menjelaskan metode penelitian yang digunakan untuk menyelesaikan rumusan masalah yang diajukan.. Metode yang digunakan bisa berupa metode kualitatif ataupun kuantitatif sesuai dengan tema penelitian yang diambil.

Objek dari penelitian ini adalah Townhouse yang berada di Kota Semarang, Diantaranya yaitu Elang Townhouse, Diamond Townhouse dan juga Beranda Bali Mundu Townhouse, yang dikaji menggunakan pendekatan kualitatif melalui analisis berbagai sumber. Sumber yang digunakan misalnya, Observasi dan pengamatan sedangkan dari sumber online berupa jurnal, artikel dari para ahli terkait dengan karakteristik Townhouse serta dari sumber lainnya.

Data yang didapat dari berbagai sumber kemudian dianalisis secara kualitatif, dengan menghubungan landasan teori dengan kondisi dan praktiknya di lapangan.

\section{HASIL PEMBAHASAN}

Bagian ini menjelaskan analisis dan pembahasan terkait studi banding objek penelitian yang dikaitkan dengan teori yang digunakan untuk mendapatkan analisa lebih mendalam terhadap objek penelitian.

\section{KESIMPULAN}

Kesimpulannya harus menyimpulkan hasil penelitian yang diperoleh dari analisa dan pembahasan berupa temuan yang hasilnya disesuaikan dengan judul Seminarnya.

\section{DAFTAR PUSTAKA}

Almusaed, A. (2011). Biophilic and Bioclimatic Architeture "Analytical Therapy for the Next Generation of Passive Sustainable Architecture. Denmark: Authors

Calabrese, E. F., Kellert, S. R. (2012). The Principles and Benefits of Biophilic Design. The Practice of Biophilic Design, 01, 6-19.

Tomphson, K., Blacksee, S. (2000) Did you hear the one about Frans Operators? Incorporating drama into the library induction. Reference Services Review. 28 (4). hlm.369378.

Samuel, P. (2003) Strategic Management. [Online] Sterling. VA Kagan Page. Available from: http://www.netlibrary.com/reader/.[ Diakses pada: 3 Juli 2015]. 